\title{
On explaining language shift: Sociology or social psychology of language ${ }^{1}$
}

PÉTER MAITZ

\begin{abstract}
This study investigates the potentials and limits of sociolinguistic research on language shift. Starting from a position that the ultimate goal of the research must be to create a general theory of language shift of predictive power, the author examines the explanatory potential of current mainstream research methodology now regarded as canonical in the practice of research. He argues for the view that, for the purposes of the research goal mentioned, the arsenal of social psychology may prove more fruitful than sociologically-based correlational-global analysis methodology. There are, however, two necessary conditions to this. On the one hand, we cannot be satisfied with a mere additive consideration of the 'subjective' psychological factors in addition to the 'objective' factors of language shift. Instead, there is a need for a general change in point of view. On the other hand, sociolinguistics needs to show greater care in treating terms, notions, and theories borrowed from social psychology in a methodologically more precise way than is reflected in today's research practice.
\end{abstract}

Keywords: sociolinguistics, language choice, language shift, social psychology of language, linguistic methodology, linguistic minorities

\section{Introductory remarks}

In the broadest possible terms, the notion of 'language shift', following Uriel Weinreich's by now classical definition, signifies the phenomenon which can be observed in unstable bi- or multilingual situations in which one community gradually changes 'from the habitual use of one language to that of another' (Weinreich 1953: 68). In this sense, language shift represents an alternative to language maintenance and usu- 
ally occurs among speech communities in a subordinate or minority position in continued language contact with a superordinate, dominant speech community.

The problem of language shift, together with language maintenance, has been at the center of both micro- and macrosociolinguistic research for several decades, based first and foremost on Joshua A. Fishman's basic, seminal writings (Fishman 1964, 1966) but equally following Susan Gal's (1979) and Nancy Dorian's (1981) classical, methodologically also significant case monographs. In recent decades numerous relevant empirical studies as well as books on theoretical and methodological issues have been published worldwide, which, on the one hand, suggests an increase in the amount of scientific knowledge pertaining to the phenomenon at issue, but it also points, at least as much, to the lack of a solution to a number of problems that researchers face even today.

The purpose of the present study is to describe the potentials and limits of the now canonical methodology employed in the course of language shift research, to formulate a few theoretical and methodological problems which I have identified, and then to delineate the principles and possibilities which, in my view, could promote the elimination of these problems and the broadening of the potentials of research.

In section 2 of my paper I will give a brief review of the possible objectives of research into language shift followed by the methodological ramifications of the diversity of these objectives. In section 3, I will give a more in-depth description of the methods used in current mainstream language shift research, trying to show, in the light of the objectives of the research, their explanatory power, and, at the same time, the limits to their explanatory value. In section 4 , I will delineate a social psychological research framework of language shift which I find promising and which is unfolding in fragments at present but differs considerably from current mainstream research in many respects. And finally, in section 5, through the example of the language choice of German speech communities in Hungary in the $19^{\text {th }}$ and $20^{\text {th }}$ centuries, I will point out the methodological advantages and the explanatory potential of this framework.

\section{The objective of language shift research}

The questions, the methodological principles, the practice and direction of the research that takes place within a given discipline are, to a great extent, determined by what position the researcher is taking in his/ her work, i.e., what (s)he considers to be the ultimate objective of the 
discipline, and, within that, his/her own research. In the case of sociolinguistic research into the phenomenon of language shift we can state that there is no consensus on this objective: the individual examinations are motivated partly by different, at times explicit, at other times latent objectives (not expressed explicitly, only detectable from the concrete way a question has been put). However, it is indispensable to clarify the ultimate goal and basic problem of the research since this objective, as I have mentioned, predetermines several elements of the actual scientific practice.

In my judgment, there are three ways in which sociolinguistic research can be carried out into language shift:

(O1) On the one hand, there is the objective of giving a general description and (possibly) predictive and causal explanation for the phenomenon at issue. In this case, then, the objective is to develop an empirical theory which would reveal the universal regularities of the phenomenon of language shift by analogy with the consequence pattern of the modus ponens type $\{\mathrm{A} \supset \mathrm{B} ; \mathrm{A}\} \Rightarrow \mathrm{B}$ logical structure (where A signifies the necessary and sufficient conditions for the occurrence of language shift, B the language shift itself, $\supset$ signifies the conditional relationship between the two, and $\Rightarrow$ signifies the valid inference). Starting from such a position and following Karl. P. Popper (1996 [1962]), we may regard language shift research and sociolinguistics, which integrates it, as a theoretical or generalizing science ('generalisierende Wissenschaft') for which individual language-shift situations only serve as means/tools for research to reveal the universal regularities of language shift, on the one hand, and to check the validity of the universal cause-and-effect rules set up through the study of individual cases on the other.

(O2) On the other hand, we can content ourselves with describing and providing the final explanation for concrete communities as the objective of our research without setting ourselves the goal of creating a universal model. In this case our research objective, in contrast with (O1), is not to explore the universal regularities of language shift, which would ideally make the prognosis of the outcome of already occurring processes possible, but rather to find an answer to the basic problem of how and why language shift does or does not take place in a concrete speech community. Such a treatment of the basic problem makes sociolinguistics and language shift research appear as a historical science ('historische Wissenschaft' - cf. ibid.) for which the language shift of individ- 
ual communities as an individual phenomenon is not a means for an ideally predictive theory of language shift but the object proper of research.

(O3) Last, but not least, research can also be motivated by everyday, practical problems or goals. In our case such a motive would be constituted by intervention in the process of language shift: to prevent, slow down, stop or reverse a given community's language shift. In this interpretation, we see sociolinguistics as an applied science ('angewandte Wissenschaft'), for which the description and explanation of language shift is not an end but a mere means. It is a tool whose function is none other than to provide an adequate scientific basis for the development of practical strategies with an objective to stop or reverse already existing/occurring language shift processes or to interfere in the language choice decisions of a community to prevent language shift. ${ }^{2}$

Let me stress that, in my view, all three trends of language shift research are, beyond doubt, legitimate, and, as I have mentioned earlier, their simultaneous presence in the practice of research can, in fact, be demonstrated through relevant literature. It is also important to note that these objectives do not necessarily and inevitably exclude one another. For example, many researchers definitely find it desirable for sociolinguistics and, within that, language shift research, to define and present itself as an applied science, e.g., as a linguistic science with social commitment and responsibility (cf., e.g., Labov 1982; Fishman 1991). This requirement in our context highlights the responsibility of (socio)linguists in preventing and reversing language shift among endangered ethnolinguistic communities. ${ }^{3}$ However, we must see that, for applied sciences to be successful, they need the results of generalizing scientific research. Similarly, an indispensable condition for the success of intervention in the process of language shift is, starting from (O1), to previously draw the generalizable conclusions, to reveal the universal regularities of language shift, and then we can apply all this knowledge to the language shift situation to be reversed, relying on the knowledge of the conditions for the success of the planned intervention and foreseeing its consequences.

To the extent, then, that the practical implementation of (O1) is really a condition for the implementation of (O3), this is likely to be a strong argument for the primacy of (O1). But even largely independent of this argument, there is a growing number of recent relevant publications discussing the present state of research. Their results and potentials seem to commit themselves implicitly or explicitly, to (O1) against 
$(\mathrm{O} 2)$. The reason for this is, as pointed out by many researchers working on language shift representing either the European or the American research traditions, that no analytical arsenal or single set of factors have been developed up to the present day that would make the causal, universal, and predictive explanation of language shift and language maintenance possible. Ammon (1991), for instance, says the following in this respect:

Allem Anschein nach ist die Erforschung der Spracherhaltung (language maintenance) noch nicht so weit vorangeschritten, dass sichere Prognosen über den Fortbestand von Sprachminderheiten möglich wären, auch dann nicht, wenn man - unrealistischerweise - das größere politisch-soziale Umfeld (Makrosystem) als konstant voraussetzt.

(Ammon 1991: 105)

'To all appearances, research into language maintenance has not yet progressed so far that clear predictions about the continued existence of language minorities are possible, not even when - unrealistically - the larger sociopolitical framework (the macrosystem) is taken to be a constant.'

Mesthrie et al. (2000), who can even see a consensus about there being no single set of factors today with the help of which it would be possible to predict the outcome of an intervention in language shift and of the efforts to maintain the language, also implicitly argue for (O1):

It is one of the few points of agreement in studies of minority and immigrant languages that there is no single set of factors that can be used to predict the outcome of language-maintenance efforts.

(Mesthrie et al. 2000: 255)

As we have seen, the statements by the authors quoted above, while not explicitly arguing for (O1), can be interpreted as implicit arguments for (O1) in that they expressly point out the lack of another, obviously desirable, causal theory of language shift. A considerably clearer and more radical stand is, for example, taken by Mattheier (1994), who, like Sándor (1999a: 599), argues explicitly for (O1) against $(\mathrm{O} 2)$. In examining the present situation and perspectives of linguistic research on 'language islands, ${ }^{4}$ he even uses the term fruchtlos ('fruitless' or 'barren') to describe the treatment of case studies not motivated by a desire to create a theory and not moving beyond a mere description of individual cases which cannot be compared methodologically, either: 
Die künftige Sprachinselforschung ... sollte die Orientierung an allgemeinen theoretisch-methodischen Fragen ... nutzen, um aus dem fruchtlosen Erarbeiten von einzelnen Fallstudien herauszukommen, das die Forschungsdiskussion leider immer noch beherrscht.

(Mattheier 1994: 345)

'Future research into language islands ... should make use of the orientation towards general, theoretical and methodological questions ... to move out of the fruitless description of individual case studies that unfortunately still dominates research discussion.'

Both of the opinions and positions quoted above and the interests of applied research into language shift support the view that, of the above three alternatives, it is expedient to view (O1), i.e., the creation of $a$ comprehensive, predictive theory of language shift, as the ultimate objective of research. ${ }^{5}$ Accepting this position, but naturally not regarding it as the only possible and acceptable one, in the next section I will also examine the potentials for and the limits of the present-day practice of language shift research expressly with (O1) in mind.

\section{The methodology of language shift research}

Language shift is perceived in most of the relevant research as linguistic change basically induced by social changes that have taken place in the life of the community concerned (cf. Bartha 1999a: 131). In this interpretation, then, the explanation of language shift based on empirical research has to start by revealing the social changes and factors which are demonstrably necessary for the process of language shift to commence and take place.

In the actual mainstream practice of research, these factors are usually found as a result of correlational-global analyses (cf. Gilles 2003: 198-200.). We can regard the analyses at hand as correlational in that, in ways similar to correlational sociolinguistics (Labov 1972) and methods used during the sociolinguistic study of language shift, research here also starts from the background assumption that certain social and functional parameters directly correlate with the language choice of the members of bilingual communities. And they can be called 'global' in the sense that the individual parameters or factors are considered to be globally relevant - or irrelevant - i.e., from the perspective of the entire community under study. In what follows let us consider the most important advantages and disadvantages of these correlational-global analyses from the perspective of the degree to which they facilitate or impede the creation of a universal theory of language shift. 


\subsection{Diversity and situation specificity of the relevant variables}

Studies of language shift research carried out in individual language communities reveal significant differences as to the issue of which social factors and parameters researchers identify as the forces of, and an explanation for, the language shift of a community under investigation. The reason for this peculiarity is twofold. On the one hand, it stems from the very nature of language shift, and on the other, it can often be explained with certain methodological inconsistencies inherent in research (for the latter see 3.2).

Since the language shift of individual communities is brought about by an accidental combination of the most diverse historical, social, cultural, political, psychological, and linguistic factors, it seems obvious that the explanation for the language shift of individual communities is first to be sought in an interdependent and situation-specific combination (combined effect) of different factors. Thus we must see that, on the one hand, the social variables relevant to the creation of the language shift as well as the concrete factors triggering it can be extremely varied, due to the uniqueness of the individual situations. On the other hand, however, the aspect of which factors play an important part in which community's language shift is at least as accidental and unique. To mention but one example: the language shift of the Yiddishspeaking Jewish community in Hungary, which had already come to an end for the most part before the holocaust, in the first half of the $20^{\text {th }}$ century, can undoubtedly be linked to the lack of a mother country. In contrast, the language shift of the German communities in Hungary or Slovakia, also in its final stage by now, obviously cannot be traced back to this factor (cf. Maitz 2005).

However, a great deal of empirical research has not only demonstrated an unambiguous presence of extraordinarily diverse factors that play a role in language shift, but also the fact that the same value of the same variable may correlate with different language choice decisions in different communities. While, for example, in the case of the Pennsylvanian Amish group or, for that matter, the Mennonites in Mexico, Paraguay or Brazil, who speak a variety of German, a marked religious and cultural separation can be demonstrably identified as a factor impeding language shift, with the Yiddish-speaking Jewish population of Hungary, the language shift did take place as part of the acculturation process, despite the initial, marked religious and cultural separation.

Practically all authors reflecting on the results and prospects of research (cf., e.g., Bartha 1999a; David 2002; Fishman 1972; Gal 1979; Kloss 1966; Mesthrie et al. 2000; Romaine 1995) have mentioned the following three features of the factors of language maintenance: 


\section{Péter Maitz}

(a) the extraordinary diversity of these factors,

(b) the accidental nature of their roles, and

(c) their often ambivalent language choice outcome.

There is also relative agreement among researchers that a self-serving taxonomic consideration of the individual factors, exactly due to these features, is hardly likely to bring research closer to creating a universal theory of language shift.

Despite its strong (self)critical edge, this recognition ultimately proved constructive, inspiring researchers (from the beginning of the 1970s) to develop typologies which set themselves the goal of creating a universally usable analytical arsenal. Among these initiatives the best known and perhaps the most influential ones are the ecology of language (Haugen 1872; Haarmann 1986), accommodation theory developed by Howard Giles et al. (Giles \& Smith 1979; Niedzielski \& Giles 1996), ethnolinguistic vitality also known in its developed version subjective ethnolinguistic vitality (Giles et al. 1977; Bourhis et al. 1981). ${ }^{6}$ An undoubted advantage of each of these initiatives is that they operate with a set of variables perceived or deemed as more or less clearly defined and generally usable. At the same time, despite their unquestionable merits and results, their critical afterlife has revealed a number of issues, internal and practical contradictions. Many of these problems also stem from the fact that they are unable to treat the diversity of the factors which potentially determine language shift; they overgeneralize in that they do not take account of factors which can be demonstrably relevant in the case of certain communities or even universally.

Thus we have to say that, although previous attempts to create models have constituted important moves forward for methodology, they also raise several serious methodological issues which, if left unanswered, impede the implementation of (O1). In light of the above, then, we basically need to agree with Maya Khemlani David, who, while examining the results of language shift research, recently arrived at the following conclusion:

At present there is no one single universally accepted paradigm for the consideration of language maintenance and language shift. This is because the range of variables and their relative values in different social and cultural contexts remain too diverse for one framework to be universally applicable.

(David 2002: vii)

Thus David, together with many other researchers, identifies the diversity of factors relevant specifically to language shift and the context- 
dependence of the values of the variables as the reason for the failure of the efforts to come up with a theory of language shift. And indeed, in addition to what has been said, there are strong arguments of a methodological nature which support the view that, in their present form, the correlational-global analyses just described are hardly likely to lead to a universal theory of language shift. In order to be able to come up with one, I believe that we need (more) exact methods of quantification and, above all, we need to develop models that draw on notional abstractions. We need patterns which, instead of an open and almost unfathomably complex matrix of variables, operate with a closed set of a relatively small, well-defined, and exactly measurable variables, while the notional abstractions would make it possible to grasp the universal regularities behind the superficial diversity. Section 4 will provide a detailed description of what a model like this could look like and how it would work. But before that I wish to touch upon the methodological inconsistencies which I, along with some other researchers, have detected and the elimination of which, I believe, is indispensable if we are to implement (O1).

\subsection{Choosing the factors examined, treating notions}

As I mentioned at the beginning of 3.1, treating notions of language shift research, individual researchers have differed greatly over what factors (intuitively defined or empirically verified) determine the language choice in bilingual communities are. Almost every one of the standard writings on the development of a theoretical and methodological framework for language shift research identifies, at least partly, different variables and factors of analysis as primary. It would be hard to even list all the factors mentioned as relevant by either theoretical or empirical research.

This situation, far from ideal from a methodological point of view, has two consequences for research. The previous section has already mentioned one: because individual researchers, by their convictions, (have) committed themselves to various theoretical and methodological principles in the course of their empirical examinations, they have often come up with results that cannot be compared or are downright contradictory. However, the theoretical and methodological crudeness of language shift research can also be demonstrated, as rightly pointed out by Csilla Bartha, in the fact that many researchers identify and study the factors considered relevant to the given community under investigation in a rather impressionistic, ad hoc manner (see Bartha 1999a: 132). Taking all these problems into account, the advantage of 
and the need for a theory of language shift which operates with a small number of precisely defined variables are obvious.

But what, in fact, are these factors of language shift, and what are they like? There is no doubt that the most frequently mentioned and studied factors, even today, are the so-called external or 'objective' variables: in addition to the well-known socio-demographic factors, the geographical location of the community, its degree of concentration, its isolation, its geographical and numerical extension, its cultural and/or religion-based separation, the level of education of its speakers, the language policy of the country, etc. (cf., e.g., Bartha 1999: 131-150; Romaine 1995: 40-43). These variables can be considered 'objective' in the sense that their values can be regarded as given even independent of the speakers' intentions and judgments, and they do not exert their effect at the level of the individual, rather their real or perceived influence affects the entire community under investigation or at least some of its groups.

These sociological, cultural, and political variables have been at the center of linguistic sociology-based, correlational-global analyses of language shift until this day. This is the situation despite the fact that certain researchers pointed out the importance of certain 'subjective' factors relatively early on. If not in the $50 \mathrm{~s}$ and $60 \mathrm{~s}$, certainly in the $70 \mathrm{~s}$ the recognition gained ground, at least among theoreticians, that certain mental or cognitive factors play a decisive role in speakers' decisions about language choice. In his seminal work published in 1972, Fishman, for that matter, warned of the importance of the psychological factors in addition to social and cultural concerns (1972: 121).

Of course, we can by no means claim that Fishman's warning - and similar warnings by others - went unheeded in (the practice of) research. After all, it was the recognition of the importance of the subjective mental factors that primarily triggered the rather fierce criticism of the (objective) model of ethnolinguistic vitality by Giles et al. and led to the revision of the model and to the development of the concept of subjective ethnolinguistic vitality, which considered subjective factors as well (see Coulmas 2005: 159-161). But even irrespective of this, today we can generally say that certain psychological but, above all, social psychological notions such as 'language attitude,' 'identity,' 'prestige,' 'stigma,' or 'ideology' all form an integral part of the analytical arsenal of language shift research. However, there has been no basic change in viewpoint in research; all we are witnessing is that in addition to the analysis of the so-called objective factors, which takes central stage even today, research consistently makes sure it considers and analyzes, in an additive manner, the role of these (social) psychological factors, too. 
However, the fact that language shift research has adapted the factors and categories of analysis mentioned, often not in a sufficiently circumspect manner, from a different discipline, most of the time from psychology, has, on several levels, led to methodological difficulties and inconsistencies. We can observe that the consideration and analysis of these 'objective' factors, somewhat similar to the case of 'subjective' variables, are rather accidental to the individual empirical studies. To mention but one example: while some language shift researchers (e.g., Bartha 1999b; Dirven \& Pütz 1996: 690; Maitz 2007) and, not least, representatives of the entire field of linguistic anthropology (cf., e.g., Irvine \& Gal 2000; Schieffelin et al. 1998) have stressed the distinguished role of linguistic ideologies, i.e., of socioculturally determined linguistic value systems in the language choice decisions of bilingual communities, this factor has not been considered in a number of empirical studies so far.

But the situation appears to be even more controversial in the field of research on language attitudes. Although at present there are hardly any studies on language shift that do not take into account speakers' language attitudes, i.e., their evaluative opinions about the given language or language variety, individual researchers attach different values to both the functions of the attitudes and the significance and aim of their studies. My observations suggest that three trends seem to be emerging more or less clearly in attitude studies carried out within language shift research:

(1) First, it is often the case that researchers study the language attitudes of individual communities for their own sake, not driven by anything other or anything more than charting speakers' language attitudes per se.

(2) Others, perhaps the majority, consider that it is the function of attitudes to influence and control human behavior (cf. Stroebe et al. 1996: 238-247) that is relevant to language shift research. Accordingly, they regard the community's negative attitudes towards its own language or language variety and its positive attitudes towards the dominant community's language or language variety as the trigger of language shift, or, at least, one of the factors inducing it.

(3) Third, there are some, perhaps careful or circumspect, researchers, who see the change in language attitudes as a peculiar concomitant of language shift, but they do not view language shift itself as derivable from speakers' attitudes towards the two languages or language varieties in contact (see, e.g., Borbély 2001: 227; Brudner \& White 1979: 65). 
As we know, 'attitude' is a genuine psychological notion borrowed by sociolinguistics and language shift research directly from social psychology. Treatment of the notion is, however, rather uncertain in language shift research, often contradicting both the rules of a methodologically adequate treatment of notions and the empirically verified position held by social psychological research. The primary reason for this may be that sociolinguistic research often uses the notion outside of its theoretical context, without giving it the necessary methodological consideration. However, the literature of social psychology, which has treated the extremely complex issue of attitudes as a distinguished field until the present day, provides rather clear instructions. In light of the literature, the following can be said about the above three trends of the study of language attitudes:

(1') Self-serving attitude studies undoubtedly disregard the decisive fact that the notion of 'attitude' is ultimately in no way the subject but only a means of human behavior research (whether in linguistic or other forms of human behavior). The notions of 'attitude' and thus also 'language attitude' are merely diversely interpreted heuristic notions. They serve to help understand human behavior and thereby linguistic behavior. The study of attitudes as subjects of study becomes legitimate only when motivated by the demand for and need of theoretical-methodological reflection. In other words, it aims to make the notion of 'attitude' more precise and check its adequacy and fruitfulness. However, this tends not to be the case in the attitude studies carried out in the bilingual communities under investigation.

(2') One of the numerous functions of attitudes, whichever interpretation of the notion it might be, is to influence and control human behavior. Accordingly, language attitude studies begin to make sense by bringing attitudes into a causal relationship with linguistic behavior itself: with language shift or language maintenance. To the extent that we regard language attitudes as indicators of linguistic behavior, their study with a view to explaining linguistic behavior (e.g., language choice) will no longer be merely legitimate but downright necessary. At the same time, we also need to see that human behavior cannot be derived from attitudes, nor can it be predicted or verified merely on their basis - and this is where the problems begin. In other words, in and by themselves, attitudes, as verified by social psychology research decades ago, are rather uncertain predictors of human behavior (see Giles et al. 1987: 591). In many cases it can be observed, especially in 
cases of strong situational duress (cf. Zimbardo \& Gerrig 1999: 247), that there is a contradiction between actual behavior and the attitudes measured. The phenomenon at hand, i.e., the inconsistent relationship between language attitudes and linguistic behavior has, incidentally, been observed and described by several researchers of bilingualism (see Macnamara 1973).

(3') The third approach mentioned, that language choice cannot be derived from speakers' language attitudes and that attitude change is merely a concomitant of language shift, is likely to stem from recognizing the above phenomenon. However, if (otherwise justified) scepticism against the heuristic values of the notion of attitude goes so far as to lead us to actually give up assuming that attitudes have a function in controlling behavior, that is, if we deny that there is a cause and effect relationship between language attitudes and language choice, we need to understand that the study of language attitudes in language shift research no longer makes sense. The notion of 'attitude,' as we have seen above, was brought into the analytical arsenal of sociolinguistics for no other reason than to help understand the causal relationships of language choice (among other things).

Let us summarize at this point what has been said so far and what are the most important lessons. So far, in the light of (O1), we have examined the potentials and limits of correlational-global analyses employed in language shift research. In harmony with numerous researchers, we have come to the conclusion that (a) the extraordinary diversity of factors involved in language shift, (b) the accidental nature of their role, and (c) their often ambivalent language choice outcome greatly impede the creation of a universal theory of language shift which would also make prediction possible. Although recognizing the significance of 'subjective,' psychological factors of language shift in addition to the external, 'objective' factors seemed promising from this aspect, in the end it turned out not to meet our expectations. One of the reasons for this, as we saw with the example of language attitudes, is likely to be the fact that research treats the notions borrowed from psychology directly, without due consideration, often in contradiction to the results and practice of psychological research.

In what follows I wish to argue for the view that it may still be the psychological, or more precisely, the socio-psychological approach that could bring language shift research closer to the implementation of (O1). However, I see two indispensable conditions for this. On the one hand, research cannot afford the luxury of treating the notions adapted 
from social psychology in an inconsistent, methodologically inadequate manner, taking them out of their theoretical context. On the other hand, closely related to this, there are serious reasons (to be elaborated later) to support the view that the additive consideration of socialpsychological factors in addition to the 'objective,' external factors of language shift will not suffice. Rather, what we need is a general change in point of view. With respect to (O1), a systematic exploration of the social psychology of language choice may promise more results than a mere understanding of the sociology of language choice.

\section{The social psychology of language shift}

First and foremost we need to see that the objective of language shift research formulated in $(\mathrm{O} 1)$ shows a striking analogy to the objective of the science of social psychology. On the one hand, research into language shift and language maintenance wishes to describe and model language shift and language maintenance as the forms of social linguistic behavior in typically bilingual communities. On the other hand, the subject of social psychology as a discipline is itself per definitionem human social behavior, and its aim is to describe, explain, and predict that behavior (Zimbardo \& Gerrig 1999: 2, 798). And if this is the case, we need to see that the phenomenon of language shift and language use embodies an unavoidable meeting point of sociolinguistics and social psychology. But we can put this in a more poignant way, too, because, taking the above two definitions seriously, we can draw the conclusion that language shift research constitutes a partial field of social psychology which deals specifically with language choice as a specific form of human social behavior. This statement may seem exaggerated, but it appears to be supported by the practice of language shift research. What else can be behind the adaptation and sociolinguistic application of genuine social psychological notions and methods? What else could make it legitimate but the analogy between the subjects and aims of the two fields of research?

I believe that it could be fruitful for language shift research to build on this analogy more consciously than at present and to make better use of the theoretical-methodological potentials that stem from this analogy. As I have mentioned before, I mean by this two needs: (a) $a$ basic change in point of view, and (b) thorough theoretical and methodological reflection.

ad (a) An additional consideration of the above mentioned social psychological factors in language shift research cannot be satisfactory. Instead, there is a need for a general change in the point 
of view. One of the reasons for this is the serious, irreconcilable difference between the correlational-global, sociologicallybased analysis of language shift on the one hand, and the social psychological approach on the other. In the focus of the former we have speech communities. Thus, the researchers who carry out sociological analyses study communities, or the - quasiglobal - effect of some external, 'objective' (e.g., social, political) factors on the language choice of the entire community, or at least some groups in the community. In contrast, social psychological research focuses primarily on the individual, or, on the effect of the (broadly interpreted) social context on the individual's behavior (cf. Fasold 1984: 187). A further irreconcilable difference between the two approaches lies in the fact that the sociologically-based, correlational-global studies are ultimately, if implicitly, behaviorist in nature. They operate with the background assumption that the language choices of individual communities (as a response) are directly affected or brought about by some objectively observable external effects (stimuli). In contradistinction to this, social psychological analysis, also relying on the notion of 'attitude,' is the exact opposite: it starts out from a mentalist position. Behind the introduction of the notion of 'attitude' lies the initial hypothesis that human behavior is controlled by directly unobservable, internal, mental processes (see Vandermeeren 1996: 692). On the basis of the above we need to see that a mere additive complementation of sociologically-based correlational-global language shift research with social-psychological factors is not simply insufficient, but, due to basic axiomatic and methodological contradictions, not even possible.

ad (b) In 3.2 we have described the view that during language shift analyses individual researchers attribute different importance to attitudes and examine them based on different positions (cf. [1]-[3]). At the same time, the empirically verified position represented by mentalist social psychology seems to be more or less united in this respect and, with certain reservations, it supports the adequacy of (2) against (1) and (3): the notion of 'attitude' covers mental factors which may be causally linked to human social behavior. We can say of language attitudes that they actually control linguistic behavior, i.e., language choice. This is true even though social-psychological research has shown us by now that in particular cases behavior may even contradict the measured attitudes. Thus, the fruitlessness of the notion of 'atti- 
tude,' its unsuitability in predicting human behaviour, does not follow from this apparent contradiction; all that is happening here is that attitudes exert their influence to control behavior together with other factors; hence all these factors need to be considered and examined in their interdependent joint effect. It is exactly this recognition that has led in recent decades to intensive theoretical and methodological research and debate in the field of social psychological research in human behavior modeling, and has proved really fruitful in the final analysis. One of its major by-products has been the development through experiments of various closed attitude-behavior models, which continue to rely on the notion of 'attitude' although they greatly relativize its role and significance. Thus, 'attitude' is only one of the notional elements of such modern social psychological theories of behavior, which, however, taken out of its theoretical context, necessarily loses its heuristic value: its explanatory and predictive power.

We can conclude from this argument that it is coherent social-psychological models of language shift which meet both requirements formulated and verified under (a) and (b), that can bring research (O1) closer to implementation. However, since there is nothing a priori to support the view that the theories of behavior developed by social psychology by now should be less valid for linguistic behavior than other forms of human social behavior, it seems obvious that language shift research should, at least on an experimental basis, in its first stage, employ the general social-psychological models of human behavior and that it should empirically test their sociolinguistic adequacy.

From among the closed social-psychological models of human behavior which build on the notion of 'attitude,' the Theory of Planned Behavior developed by Icek Ajzen and Thomas Madden can be considered today to be one of the most influential and most widespread theories (see Stroebe et al. 1996: 247; Zimbardo \& Gerrig 1999: 247). It was created as a modification to and an extension of the Theory of Reasoned Action. ${ }^{7}$ Due to its influence and popularity I will give a brief description of this theory as a possible theory for the explanation of language shift, a possible framework for the interpretation of the phenomena followed by a digression into its advantages over correlationalglobal analyses.

The Theory of Planned Behavior basically derives human social behavior from four factors (cf. fig.1). It regards the individual's intention (as an indication of a person's readiness to perform a given behavior) as the immediate antecedent of behavior, i.e., the acting individual's 


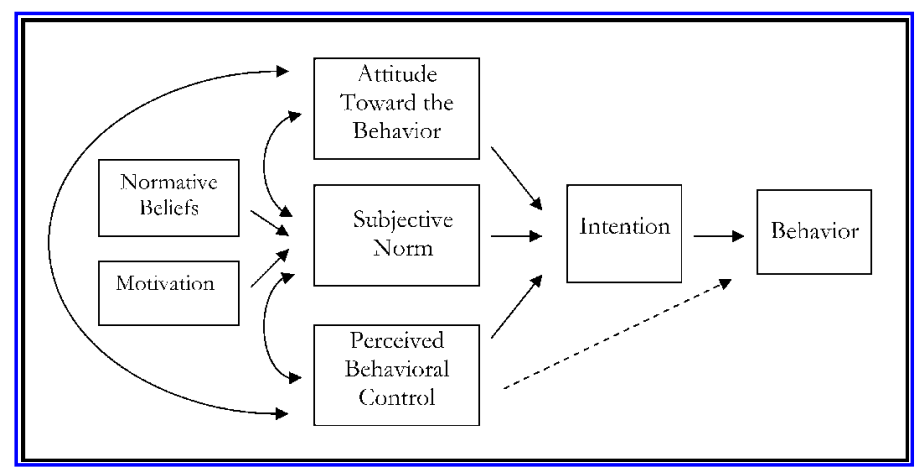

Figure 1. Theory of Planned Behavior (based on Stroebe et al. 1996: 248 and Frey et al. 1993: 379).

intention to implement or not implement the behavior at hand. This intention is, in turn, based on three further factors. The first factor is the individual's attitude toward the given behavior, i.e., the individual's positive or negative judgment of the implementation of the behavior. The second factor, the so-called 'subjective norm,' is to be interpreted as the perceived social pressure for the implementation or non-implementation of the behavior at hand. The role of this factor is extremely important because - as pointed out by Brudner and White in connection with their investigations in Ireland as early as 1979 - in a particular case this pressure (due to the community's norms, expectations, social, political, or psychological pressure from the predominant outgroup, etc.) may be so strong that the individual may carry out the given behavior despite his/her definitely negative attitude towards it. These are, then, the cases we mentioned earlier in which actual behavior can run counter to the value of attitudes (cf. sections 3.2 and 5). This subjective norm, is, in turn, influenced by two further factors, on the one hand, by the expectations of the persons relevant to the individual (such as friends, partner, office superior, parish priest, etc.) as normative beliefs; on the other hand, the individual's own motivation to really meet these expectations. An earlier version of the theory, the Theory of Reasoned Action, derives human social behavior from the above variables. However, the Theory of Planned Behavior contains a further factor in addition to those components, the so-called 'perceived behavioral control,' proved by empirical experiments to make more precise predictions of behavior possible. This component refers to people's perceptions of their ability to perform a given behavior, and it can be conceptualized as the expected or perceived ease or difficulty of the implementation of the individual's planned behavior. This con- 
trol of the behavior may be based on the individual's own experience and observations, but at least as much on other people's experience and observations, too. It exerts its effect on behavior directly but also indirectly, like attitudes and subjective norm, through intention. Certain interdependent relations exist among the components of the theory as shown in figure 1.

To the extent, then, that we consider language shift (or, looking at it on the level of the individual, language $\operatorname{loss}^{8}$ ) a form of social behavior based on individual decisions, within the Theory of Planned Behavior the phenomenon can be given the following explanation (highly simplified):

(a) Intention. A speaker undergoes language shift, i.e., trades in his/ her own language or language variety for the majority community's dominant language if and only if (s)he intends to do so. The existence or formation of this intention can be traced back to the following factors:

(aa) Attitudes. The speaker believes that language shift, i.e., giving up his/her own language or language variety for the dominant language will result in positive consequences. His/her attitude towards language shift as behavior and towards the dominant language is positive, or at least more markedly positive than his/her attitude towards language maintenance and his/her own language.

(ab) Subjective norm. The people relevant to the speaker have expected language shift or deemed it desirable, on the one hand, and on the other, the speaker him/herself is also motivated to meet the requirements and needs, i.e., to implement language shift as behavior.

(ac) Perceived behavioral control. The speaker thinks that (s)he can easily solve all the difficulties and problems which argue against language shift or could accompany it (such as mastering the other language, possible identity problems related to the language shift, etc.). In other words, (s)he believes that the planned behavior (i.e., language shift) can be carried out with relative ease and in a problem-free way.

\section{Methodological advantages of the social psychological approach}

The further, detailed review of the theory would go beyond the scope of the present study, hence I will not provide a further clarification of the elements of the conceptual arsenal, or the theory-related explora- 
tion and measurement procedures. ${ }^{9}$ Due to scope constraints, I will only make an attempt to give a brief description of the methodological advantages of the socio-psychological approach over correlationalglobal analyses, through the example of the German-speaking communities in $19^{\text {th }}$ and $20^{\text {th }}$ century Hungary, relying on the results of Maitz (2005).

From the perspective of language behavior, two large types of German speech community can be distinguished in the second half of the $19^{\text {th }}$ century in Hungary. On the one hand, there was the layer of the bourgeoisie concentrated in towns, whose speakers were unambiguously characterized by language shift. The radical change in these speakers' language choice is borne out by statistical figures for contemporary Budapest: while in 1850 almost half, 48.8 percent, of the city's population used German as their mother tongue, in 1900, only 14 percent of the population declared themselves German in terms of their mother tongue (cf. Maitz 2007: 409). In contrast, a remarkably different picture emerges in the German communities living in the German monolingual or dominantly German-speaking villages which made up mostly closed blocks (then) in several parts of Hungary. In these communities, the German language remained dominant for as long as the turn of the century. What is more, the proportion of the German element within the population increased in some cases, e.g., in Nagytevel/ Deutschtewel, north of Lake Balaton, this ratio grew from 75.9 percent in 1880 to 87.95 percent in 1900 (cf. Hutterer 1961: 61).

If we are to explain these marked differences in the language choice within the framework of a 'traditional,' correlational-global analysis, the following aspects need to be considered.

Many of the factors employed and analyzed in correlational-global analyses appear to be inherently ambivalent or irrelevant. The size of a community, for example, is generally considered to feature among factors advancing language maintenance in that it makes it possible to develop and maintain more extensive social networks in the given language, thereby increasing the language's functionality and market value. In our case, however, we are witnessing the fact that language shift is characteristic of larger urban speech communities rather than small villages with a small population. Official state language policy cannot be a decisive factor, either, since these policies can be considered identical in each of these communities and given from the beginning, independent of them. Likewise, religion does not seem to be a significant factor, either, since language shift in the towns affected both Christian and Jewish German language communities alike, while in the villages language maintenance was characteristic both of Evangelical and Catholic communities. If we want to find an explanation for the 
differences between language choice in 'surface' factors, i.e., the features characteristic of the given sociohistorical situation, which hence do not lend themselves to generalization, then, based on contemporary sources, we can set up the following correlations (cf. Maitz 2005).

(1) Major factors advancing language shift typical of German communities living in towns:

(a) collective multilingualism, steady coexistence with large Hungarian speech communities and the concomitant low density and complexity of social networks (cf. Milroy 1980: 179);

(b) exogamy resulting from this coexistence;

(c) the limited communicative functionality of the German language resulting from the towns' multilingualism;

(d) the system of language norms and linguistic values carried by linguistic nationalism, the dominant language ideology among the Hungarian bourgeoisie;

(e) the high social prestige of Hungarian as the national language resulting from linguistic nationalism;

(f) the stigmatized nature of the German language as the symbol and means of Habsburg oppression and impediment to national (linguistic) unity;

(g) the Hungarian national identity of German communities and their concomitant identification with the value and norm system of Hungarian linguistic nationalism;

(h) social pressure exerted by the politically dominant Hungarian speech communities via social and political discourse.

(2) Major factors promoting language maintenance characteristic of the (closed) German speech communities of villages:

(a) the communitiy's closed nature;

(b) the concomitant dense and multiplex social networks;

(c) endogamy;

(d) the practically unlimited functionality of the local German vernacular resulting from the closed nature and oral culture of the community;

(e) language loyalty traceable to the vernacular's function to carry ethnic and group identity;

(f) a lack of social pressure by the politically dominant Hungarian speech communities resulting from the closed nature of these communities.

Although an explanation of language choice based on the above correlations certainly seems plausible, it also raises several issues at the same 
time. The biggest among these, in my view, is the overgeneralization which we have referred to earlier. On the one hand, we need to see that obviously there were atypical instances of language choice, too, which diverted from the dominant behavior within the urban as well as the rural communities. There were cases, although a much smaller number of them, of language maintenance within the German population of towns as there were of language shift in the speech communities of villages. In addition to this, several other concrete circumstances and individual motivations may also play a role in decisions on language choice that can be generalized only in a limited way or not at all.

In my view, the Theory of Planned Behavior is able to remedy this methodological problem by operating with a closed and universally applicable set of variables. Last but not least, due to the Likert-based measurement and quantification procedure, it enables us to explain even language choice decisions which have so far been explained only in an ad hoc manner. A case in point is language shift brought about as a result of extremely strong situational duress (e.g., political oppression), which may be realized even despite the speakers' positive attitude towards their own language. One such case is the language shift that took place among village-dwelling German communitites in Hungary, which showed a radical increase after WWII, following the language maintenance observed in the $19^{\text {th }}$ century and the first part of the $20^{\text {th }}$ century. In this process a major role was played by those political and legal reprisals (e.g., mass deportations, confiscation of possessions, etc.) with which Hungarian state power afflicted Germans living in the territory of Hungary in the post-WWII years, following the principle of collective guilt (cf. Maitz \& Sándor 2009: 155-157). Following that period, German communities living in Hungary that avoided deportation used language shift as a strategic means of avoiding social stigmatization and reprisals. The Theory of Planned Behavior does not lead to ad hoc explanations of these and similar situations, either, not even if the speakers' (emotional) language attitudes towards their mother tongue continue to be positive and obviously are not likely to change from positive to negative overnight, even despite the political and legal pressure. In the cases of the communities in Hungary mentioned contemporary linguistic reflections proved the speakers' positive emotional attitude towards their mother tongue. This, undoubtedly, leads to an inconsistency in the relationship between attitudes and language behavior, which, however, is counteracted by the values of the model's further variables. In these and similar cases the values of the subjective norm (the speakers' normative beliefs and motivations) and the perceived behavioral control (the perceived negative consequences 
of maintaining their language) are so high as to lead to language shift even with (relatively) positive attitiudes.

To sum up, based on the above, I can see the advantages of a coherent, social-psychologically-based theory of language shift, and specifically, the promising nature of the Theory of Planned Behavior for language shift research, in contrast with the sociological approach, in the following points:

(1) Unlike the factors used in sociological analyses, the model, through notional abstractions, greatly facilitates the grasping of the general regularities behind the superficial diversity of individual languageshift situations.

(2) It is due to these notional abstractions, too, that this model is closed and operates with a relatively small set of well-defined variables. This makes it more suitable for the principle of methodological minimalism: both the description and the explanation are significantly simpler and more transparent when compared with correlational-global analyses.

(3) The explanation focuses on the speaker him/herself as an acting individual rather than on objective factors which are abstracted away from speakers and made independent. In this approach the issue is not the absence or presence of some external, 'objective' factors, rather, it is the way the speaker perceives and judges them in their interdependent joint effect and the way (s)he judges them from the perspective of the planned language choice decision.

(4) Finally, the fact that the analysis does not take place at the level of the community but at that of the individual can make both the description and the explanation significantly more adequate, free from overgeneralizations. This is relevant because the implicit assumption of sociologically-based community-level correlationalglobal analyses that certain 'objective' factors (e.g., exogamy, language policy, isolation, etc.) influence the language choice of the entire community (or a group within it) to the same degree or in the same direction leads to overgeneralizations.

The phenomenon of language shift can obviously be grasped or explained more precisely at the level of the individual, also counting with the subjective, individual circumstances of and motivations for language choice rather than at the level of the community postulated as homogeneous in respect of certain factors (cf. Appel \& Muysken 1987: 42). While the sociological approach only makes it possible to identify 
tendencies which by necessity contain overgeneralizations, the socialpsychological approach, with the individual in focus, makes it possible to reveal the rules.

Recently I have made an attempt to use the theory outlined above in historical sociolinguistics (cf. Maitz 2005). It was my intention to describe and explain the language shift of the German-speaking bourgeoisie in nineteenth century Hungary through the corpus-based reconstruction of the variables suggested by the Theory of Planned Behavior. The result of the reconstruction unambiguously supported the usability of the theory in (historical) sociolinguistics. However, the fact that the language shift situation and speech community I studied now belong to the historical past, brought with it the well-known methodological difficulties of historical social science and, among them, historical sociolinguistics: due to the unavailability of the speakers, systematic data collection or attitude measurement were impossible. Thus, even despite the relative abundance of data and the differentiated nature of the sources available to me, the consequences I drew are in need of further empirical confirmation. To this end, we obviously need studies in future which analyze the social psychology of language choice within living communities which can be exhaustively and systematically explored, empirically checking the adequacy - or untenability - of the position which I represent and which I have tried to verify.

\section{Closing remarks}

The purpose of the present paper was to constructively and critically analyze the methodology of current mainstream language shift research. I hope that, with the help of the above thoughts, I have succeeded in pointing out why and to what extent the systematic, scientific, methodologically reflected exploration of the social psychology of language shift can promote the creation of a universal, predictive theory of language shift. Thus, in my view, interpreting language shift and language maintenance as social behavior could be extremely fruitful for sociolinguistics providing it does not remain an empty phatic slogan, but rather we draw the necessary conclusions from this not-too-strong presupposition and providing it really takes us to social psychology: the science of human social behavior. It is not just some notions that social psychology offers to sociolinguistics to describe and model linguistic behavior but also closed theories of behavior, something that sociolinguistics does not seem to have paid sufficient attention to so far (cf. Giles \& Fortman 2004; Robinson \& Giles 2001). Through their use, empirical testing, possible modification or, for that matter, falsification, sociolinguistics can not only get closer to understanding the universal 
regularities of language shift (or language maintenance), but it can also play a role in researching human behavior in that it checks the validity of social psychological theories of behavior by examining language maintenance and shift as forms of social (linguistic) behavior.

Thus the research carried out in the two disciplines may understandably be fruitful for each other in this respect. I think, however, that there is an indispensable condition of this fruitful interdisciplinary relationship: the mutual uptake of the theoretical, methodological and empirical results of the two disciplines on a more intensive and more circumspect level than at present.

University of Pécs

\section{Notes}

1. The present paper is partly the outcome of the research which I was able to carry out at the University of Augsburg between 2006 and 2008 as an Alexander von Humboldt research fellow. The paper contains the detailed elaboration of the theoretical and methodological views which I have used in an earlier experimental work on the language shift of the German bourgeoisie in $19^{\text {th }}$ century Hungary (cf. Maitz 2005). For valuable remarks and advice on earlier versions of the manuscript I am grateful to Klaus J. Mattheier, Anna Borbély, Anna Molnár, and Klára Sándor. Any mistakes made are my sole responsibility.

2. Borbély (2003: 104) finds partly similar research goals possible, with the difference that she does not make a sharp distinction between (O1) and (O2); however, she regards the description and explanation of language shift as two separate, autonomous objectives.

3. In many countries of Central-Eastern Europe, as in numerous other countries of the world, there are even today monolingual ideology-based language policies and political practices, problematic both linguistically and from the aspect of linguistic human rights, which carry in them the danger of language shift. We can mention, for example, the less known case of the Csángós in Romania (cf. Sándor 1999b, 2000) or the 2009 amendment of the Act on the State Language of the Slovak Republic, which has been criticized by several people as well as political and linguistic organizations (cf. Research Institute for Linguistics of the Hungarian Academy of Sciences 2009) for restricting the freedom of choice of the language of communication of linguistic minorities and even the freedom of language use of speakers of the state language.

4. While in the American tradition research into language islands (speech communities in a minority status, which, however, have a linguistic mother country) belongs to the field of research known as 'language contact,' 'bilingualism,' and 'language variation,' in German studies this field has become institutionalized by the term 'Sprachinselforschung' ('research into language islands') and has now acquired a relatively autonomous status (cf. Mattheier 1994: 333; Berend \& Mattheier 1994; Berend \& Knipf-Komlósi 2006).

5. It is debatable whether it is a realistic goal to create a universal, predictive theory of language shift. For those sceptical minds, however, who really deny the possibility of such a theory, it may be useful to point out that the science of psychology has achieved significant results, despite the (superficial) uniqueness of human 
behavior, in developing models of human behavior with a view to coming up with an explanation of universal scope. And while, naturally, these models of behavior are not perfect, either, we must still not see this shortcoming as a circumstance supporting the unrealistic nature of the goal of model-creating; the lack of precision and perfection are merely signs and concomitants of the on-going, not yet finished process of research.

6. For a critical appraisal see, e.g., Appel \& Muysken (1987), Bartha (1999a), Coulmas (2005), and Sercombe (2002).

7. Cf. Ajzen \& Madden (1986), Ajzen (1991), and Fishbein \& Ajzen (1975). For a content review of the theory, an in-depth critical appraisal of its empirical basis, experimental background, and pre- and post-history, see Frey et al. (1993).

8. Since the range of interpretation of the notion of 'language shift' is the community, whereas the object of the theory of planned behavior is not collective, but rather, individual behavior, in the rest of the paper I should be speaking of language loss instead of language shift as a particular manifestation of the phenomenon. I shall not do so for the sake of simplicity and will try and reduce the terminological density of the text.

9. For a further description of the theory with a detailed bibliography, a sample questionnaire and other relevant information, cf. the TPB home page.

\section{References}

Ajzen, Icek. 1991. The theory of planned behavior. Organizational Behavior and Human Decision Processes 50. 179-211.

Ajzen, Icek \& Thomas J. Madden. 1986. Prediction of goal directed behavior: Attitudes, intentions, and perceived behavioral control. Journal of Experimental Social Psychology 22. 453-474.

Ammon, Ulrich. 1991. Die internationale Stellung der deutschen Sprache. Berlin \& New York: Walter de Gruyter.

Ammon, Ulrich, Norbert Dittmar \& Klaus J. Mattheier (eds.). 1987. Sociolinguistics: An international handbook of the science of language and society, vol. 1. Berlin \& New York: Walter de Gruyter.

Ammon, Ulrich, Norbert Dittmar, Klaus J. Mattheier \& Peter Trudgill (eds.). 2004. Sociolinguistics: An international handbook of the science of language and society, 2nd ed, vol. 1. Berlin \& New York: Walter de Gruyter.

Androutsopoulos, Jannis \& Evelyn Ziegler (eds.). 2003. 'Standardfragen'. Soziolinguistische Perspektiven auf Sprachgeschichte, Sprachkontakt und Sprachvariation. Frankfurt am Main: Peter Lang.

Appel, René \& Pieter Muysken. 1987. Language contact and bilingualism. London: Edward Arnold.

Bartha, Csilla. 1999a. A kétnyelvúség alapkérdései. Budapest: Nemzeti Tankönyvkiadó.

Bartha, Csilla. 1999b. A purista nyelvideológiák szerepe a nyelvcsere folyamatában. In Nóra Kugler \& Klára Lengyel (eds.), Ember és nyelv. Tanulmánykötet Keszler Borbála tiszteletére, 44-54. Budapest: ELTE BTK Mai Magyar Nyelvi Tanszék.

Berend, Nina \& Klaus J. Mattheier (eds.). 1994. Sprachinselforschung. Eine Gedenkschrift für Hugo Jedig. Frankfurt am Main: Peter Lang.

Berend, Nina \& Elisabeth Knipf-Komlósi (eds.). 2006. Sprachinselwelten - The World of Language Islands. Frankfurt am Main: Peter Lang.

Borbély, Anna. 2001. Nyelvcsere. Budapest: MTA Nyelvtudományi Intézetének Élőnyelvi Osztálya. 
Borbély, Anna. 2003. A nyelvcsere kutatásának módszerei. In Szergely Tóth (ed.), Nyelvek és kultúrák találkozása, 104-108. Szeged: SzTE JGyTFK Alkalmazott Nyelvészeti Tanszék.

Bourhis, Richard Y., Howard Giles \& Doreen Rosenthal. 1981. Notes on the construction of a 'Subjective Ethnolinguistic Vitality Questionnaire' for ethnolinguistic groups. Journal of Multilingual and Multicultural Development 2. 145157.

Brudner, Lilyan A. \& Douglas R. White. 1979. Language attitudes: Behavior and intervening variables. In William Francis Mackey \& Jacob Ornstein (eds.), Sociolinguistic studies in language contact: Methods and cases, 51-68. The Hague: Mouton.

Carl, Jenny \& Patrick Stevenson (eds.). 2009. Language, discourse and identity in Central Europe: The German language in a multilingual space. Basingstoke: Palgrave Macmillan.

Coulmas, Florian. 2005. Sociolinguistics: The study of speakers' choices. Cambridge: Cambridge University Press.

David, Khemlani Maya (ed.). 2002. Methodological and analytical issues in language maintenance and language shift studies. Frankfurt am Main: Peter Lang.

David, Khemlani Maya. 2002. Preface. In Maya Khemlani David (ed.), Methodological and analytical issues in language maintenance and language shift studies, viix. Frankfurt am Main: Peter Lang.

Dil, Anwar S. (ed.). 1972. The ecology of language. Essays by Einar Haugen. Stanford: Stanford University Press.

Dirven, René \& Martin Pütz. 1996. Sprachkonflikt. In Hans Goebl, Peter H. Nelde, Zdenek Starý \& Wolfgang Wölck (eds.), Contact linguistics: An international handbook of contemporary research, vol. 1., 684-691. Berlin \& New York: Walter de Gruyter.

Dorian, Nancy C. 1981. Language death: The life cycle of a Scottish Gaelic dialect. Philadelphia: University of Pennsylvania Press.

Elspaß, Stephan, Nils Langer, Joachim Scharloth \& Wim Vandenbussche (eds.). 2007. Germanic language histories 'from below' (1700-2000). Berlin \& New York: Walter de Gruyter.

Fasold, Ralph W. 1984. The sociolinguistics of society. Oxford \& Cambridge: Blackwell.

Fishbein, Martin \& Icek Ajzen. 1975. Belief, attitude, intention, and behavior: An introduction to theory and research. Reading, MA: Addison-Wesley.

Fishman, Joshua A. 1964. Language maintenance and language shift as a field of inquiry. Linguistics 9. 32-70.

Fishman, Joshua A. (ed.). 1966. Language loyalty in the United States: The maintenance and perpetuation of non-English mother tongues by American ethnic and religious groups. The Hague: Mouton.

Fishman, Joshua A. 1972. The sociology of language: An interdisciplinary social science approach to language in society. Rowley, MA: Newbury.

Fishman, Joshua A. 1991. Reversing language shift: Theoretical and empirical foundations of assistance to threatened languages. Clevedon: Multilingual Matters.

Frey, Dieter, Dagmar Stahlberg \& Peter M. Gollwitzer. 1993. Einstellung und Verhalten: Die Theorie des überlegten Handelns und die Theorie des geplanten Verhaltens. In Dieter Frey \& Martin Irle (eds.), Theorien der Sozialpsychologie. Vol. 1: Kognitive Theorien, 361-398. Bern: Hans Huber.

Frey, Dieter \& Martin Irle (eds.). 1993. Theorien der Sozialpsychologie. Vol. 1: Kognitive Theorien. Bern: Hans Huber.

Gal, Susan. 1979. Language shift: Social determinants of linguistic change in bilingual Austria. New York: Academic Press. 
Giles, Howard (ed.). 1977. Language, ethnicity, and intergroup relations. New York: Academic Press.

Giles, Howard, Miles Hewstone, Ellen B. Ryan \& Patricia Johnson. 1987. Research on language attitudes. In Ulrich Ammon, Norbert Dittmar \& Klaus J. Mattheier (eds.), Sociolinguistics: An international handbook of the science of language and society, vol. 1, 585-597. Berlin \& New York: Walter de Gruyter.

Giles, Howard, Richard Y. Bourhis \& Donald M. Taylor. 1977. Towards a theory of language in ethnic group relations. In Howard Giles (ed.), Language, ethnicity, and intergroup relations, 307-348. New York: Academic Press.

Giles, Howard \& Jennifer Fortman. 2004. The social psychology of language. In Ulrich Ammon, Norbert Dittmar, Klaus J. Mattheier \& Peter Trudgill (eds.), Sociolinguistics: An international handbook of the science of language and society, 2nd ed., vol. 1, 99-108. Berlin \& New York: Walter de Gruyter.

Giles, Howard \& Philip M. Smith. 1979. Accommodation theory: Optimal levels of convergence. In Howard Giles \& Robert N. St Clair (eds.), Language and social psychology, 45-65. Oxford: Blackwell.

Giles, Howard \& Robert N. St Clair (eds.). 1979. Language and social psychology. Oxford: Blackwell.

Gilles, Peter. 2003. Zugänge zum Substandard: Korrelativ-globale und konversationell-lokale Verfahren. In Jannis Androutsopoulos \& Evelyn Ziegler (eds.), 'Standardfragen'. Soziolinguistische Perspektiven auf Sprachgeschichte, Sprachkontakt und Sprachvariation, 195-215. Frankfurt am Main: Peter Lang.

Goebl, Hans, Peter H. Nelde, Zdenek Starý \& Wolfgang Wölck (eds.). 1996. Contact linguistics: An international handbook of contemporary research, vol. 1. Berlin \& New York: Walter de Gruyter.

Grosse, Rudolf \& Claus Jürgen Hutterer (eds.). 1961. Hochsprache und Mundart in Gebieten mit fremdsprachigen Bevölkerungsteilen. Berlin: Akademie-Verlag.

Haarmann, Harald. 1986. Language in ethnicity: A view of basic ecological relations. Berlin: Mouton.

Haugen, Einar. 1972. The stigmata of bilingualism. In Anwar S. Dil (ed.), The ecology of language. Essays by Einar Haugen, 307-344. Stanford: Stanford University Press.

Hutterer, Claus Jürgen. 1961. Hochsprache und Mundart bei den Deutschen in Ungarn. In Rudolf Grosse \& Claus Jürgen Hutterer (eds.), Hochsprache und Mundart in Gebieten mit fremdsprachigen Bevölkerungsteilen, 33-71. Berlin: Akademie-Verlag.

Irvine, Judith T. \& Susan Gal. 2000. Language ideology and linguistic differentiation. In Paul V. Kroskrity (ed.), Regimes of language: Ideologies, polities, and identities, 35-83. Santa Fe: School of American Research Press.

Kloss, Heinz. 1966. German-American language maintenance efforts. In Joshua A. Fishman (ed.), Language loyalty in the United States, 206-252. The Hague: Mouton.

Kontra, Miklós, Robert Phillipson, Tove Skutnabb-Kangas \& Tibor Várady (eds.). 1999. Language: A right and a resource. Approaching linguistic human rights. Budapest: CEU Press.

Kroskrity, Paul V. (ed.). 2000. Regimes of language: Ideologies, polities, and identities. Santa Fe: School of American Research Press.

Labov, William. 1972. Sociolinguistic patterns. Philadelphia: University of Pennsylvania Press.

Labov, William. 1982. Objectivity and commitment in linguistic science: the case of the Black English trial in Ann Arbor. Language in Societv 11. 165-201.

Mackey, William Francis \& Jacob Ornstein (eds.). 1979. Sociolinguistic studies in language contact: Methods and cases. The Hague: Mouton. 
Macnamara, John. 1973. Attitudes and learning a second language. In Roger W. Shuy \& Ralph W. Fasold (eds.), Language attitudes: Current trends and prospects, 36-40. Washington: Georgetown University Press.

Maitz, Péter. 2005. Sozialpsychologie des Sprachverhaltens. Der deutsch-ungarische Sprachkonflikt in der Habsburgermonarchie. Tübingen: Niemeyer.

Maitz, Péter. 2007. The death of standard German in nineteenth-century Budapest: A case study on the role of linguistic ideologies in language shift. In Stephan Elspaß, Nils Langer, Joachim Scharloth \& Wim Vandenbussche (eds.), Germanic language histories 'from below' (1700 2000), 405-421. Berlin \& New York: Walter de Gruyter.

Maitz, Péter \& Klára Sándor. 2009. Changes in the linguistic marketplace: The case of German in Hungary. In Jenny Carl \& Patrick Stevenson (eds.), Language, discourse and identity in Central Europe: The German language in a multilingual space, 149-164. Basingstoke: Palgrave Macmillan.

Mattheier, Klaus J. 1994. Theorie der Sprachinsel. Voraussetzungen und Strukturierungen. In Nina Berend \& Klaus J. Mattheier (eds.), Sprachinselforschung. Eine Gedenkschrift für Hugo Jedig, 333-348. Frankfurt am Main: Peter Lang.

Mesthrie, Rajend, Joan Swann, Andrea Deumert \& William L. Leap. 2000. Introducing sociolinguistics. Edinburgh: Edinburgh University Press.

Milroy, Leslie. 1980. Language and social networks. Oxford: Basil Blackwell.

National Council of the Slovak Republic. 1995. Act on the State Language of the Slovak Republic. http://www.culture.gov.sk/en/legislation/jazykov-zkon-anglickverzia (accessed 10 January 2010).

Niedzielski, Nancy \& Howard Giles. 1996. Linguistic accommodation. In Hans Goebl, Peter H. Nelde, Zdenek Starý \&Wolfgang Wölck (eds.), Contact linguistics: An international handbook of contemporary research, vol. 1, 332-342. Berlin \& New York: Walter de Gruyter.

Popper, Karl R. 1996 [1962]. Über Geschichtsschreibung und über den Sinn der Geschichte. In Karl R. Popper, Alles Leben ist Problemlösen. Über Erkenntnis, Geschichte und Politik, 173-205. München: Piper.

Research Institute for Linguistics of the Hungarian Academy of Sciences. 2009. Statement on the Amendment of the Language Law in Slovakia. http://peticio.nytud. $\mathrm{hu} /$ (accessed 10 January 2010).

Robinson, William P. \& Howard Giles (eds.). 2001. The new handbook of language and social psychology. New York: Wiley.

Romaine, Suzanne. 1995. Bilingualism. $2^{\text {nd }}$ ed. Oxford \& Cambridge: Blackwell.

Sándor, Klára. 1999a. A megtalált paradigma. Magyar filozófiai szemle 4-5. 595606.

Sándor, Klára. 1999b. Contempt for linguistic human rights in the service of the catholic church: The case of the Csángós. In Miklós Kontra, Robert Phillipson, Tove Skutnabb-Kangas \& Tibor Várady (eds.), Language: A right and a resource. Approaching linguistic human rights, 317-331. Budapest: CEU Press.

Sándor, Klára. 2000. National feeling or responsability: The case of the Csángó language revitalization. Multilingua 19(1/2). 141-168.

Schieffelin, Bambi B., Kathryn A. Woolard \& Paul V. Kroskrity (eds.). 1998. Language ideologies: Practice and theory. New York and Oxford: Oxford University Press.

Sercombe, Peter. 2002. Language maintenance and shift: a review of theoretical and regional issues with special reference to Borneo. In Maya Khemlani David (ed.), Methodological and analytical issues in language maintenance and language shift studies, 1-19. Frankfurt am Main: Peter Lang.

Shuy, Roger W. \& Ralph W. Fasold (eds.). 1973. Language attitudes: Current trends and prospects. Washington: Georgetown University Press. 
Stroebe, Wolfgang, Miles Hewstone \& Geoffrey M. Stephenson (eds.). 1996. Sozialpsychologie. Eine Einführung. 3. ed. Berlin: Springer.

TPB home page: http://www.people.umass.edu/aizen/tpb.html. (accessed 10 January 2010).

Vandermeeren, Sonja. 1996. Sprachattitüde. In Hans Goebl, Peter H. Nelde, Zdenek Starý, and Wolfgang Wölck (eds.), Contact linguistics: An international handbook of contemporary research, vol. 1, 692-702. Berlin \& New York: Walter de Gruyter.

Weinreich, Uriel. 1953. Languages in contact: Findings and problems. New York: Linguistic Circle.

Zimbardo, Philip G \& Richard J. Gerrig. 1999. Psychologie. 7. Newly translated and adapted edition. Berlin: Springer.

Péter Maitz pursued German and Polish Studies in Debrecen, Hungary and Heidelberg and is currently assistant professor in the German Department of the University of Pécs, Hungary. He holds a PhD in German Linguistics from the University of Debrecen. His research interests include sociolinguistic theory and methodology, bilingualism, language ideologies, the interrelationship between language, identity and power as well as various topics in historical sociolinguistics.

Address for correspondence: University of Pécs, Institute of German Studies, Ifjúság útja 6, H-7624 Pécs, Hungary.

e-mail: mensaje30@hotmail.com 